\title{
Poverty in Pakistan: Increasing Incidence, Chronic Gender Preponderance, and the Plausibility of Grameen-type Intermediation
}

\author{
NABEEL A. GOHEER \\ ECONOMIC GROWTH AND CONSUMPTION POVERTY
}

Pakistan is a large country with a population estimated at 130.580 million. ${ }^{1}$ The economy has a low-income of US\$ 490 per capita, with an estimated Purchasing Power Parity (PPP) of US\$ $2230 .^{2}$ It has managed to achieve substantial economic growth in the past thirty years until the dawn of 1990s. The growth rate has averaged 6.8 percent, 4.8 percent and 6.5 percent in $1960 \mathrm{~s}, 70 \mathrm{~s}$ and $80 \mathrm{~s}$, respectively. ${ }^{3}$

Evidence from the National Income Accounts, Household Surveys and time series data on the real wages of unskilled workers shows that economic growth has contributed to reduce consumption poverty ${ }^{4}$ in Pakistan. The table placed as Appendix A at the end shows that GDP per capita has increased in real terms by about 63 percent between 1972-73 and 1990-91. Private consumption per capita also increased in real terms by about 36 percent. Despite the fact that the population has nearly doubled during the period, there have been gains in income and consumption in per capita terms. ${ }^{5}$

Further evidence of the decline in consumption poverty comes from various research studies in the past. These studies have generally used Household Integrated Economic Surveys (HIES) and estimated the incidence of poverty by using various definitions (absolute poverty, poverty of basic needs, consumption Islamabad.

Nabeel A. Goheer is Special Assistant to the Deputy Chairman, The Planning Commission, July 1998.

l"Population and Housing Census of Pakistan 1998" Statistics Division, Government of Pakistan

${ }^{2}$ World Development Report 1997, World Bank, Washington, D. C.

3“"Assessing Poverty in Pakistan" by Dr S. M. Younus Jafri 1998 in "A Profile of Poverty in Pakistan" compiled by Human Development Centre, Islamabad.

${ }^{4}$ Consumption poverty is often used to reflect the general level of poverty. Pakistan Poverty Assessment Report 1995 of the World Bank states that consumption poverty is the extent to which actual levels of private consumption of households or individuals fall below a "poverty line" that society believes represents a minimum acceptable standard of private consumption.

${ }^{5}$ Pakistan Poverty Assessment 1995, World Bank, Washington, D. C. 
poverty etc.) and different methodologies (poverty line, minimum required calories, calorie intake, household consumption etc.). Jafri (1999) in his comprehensive review of the literature has mentioned 25 previous studies on the estimation of poverty in Pakistan. The estimates generated by these studies are not strictly comparable but they also show a decline in the incidence of consumption poverty from the period 1970 to 1990 . The latest study [Jafferi and Khattak (1995)] however, shows that the trend has reversed in the 1990s and absolute poverty has started rising again. ${ }^{6}$

\section{INVERSE TRENDS OF POVERTY AND GROWTH IN 1990s}

The economic difficulties of the 1990s have worsened the poverty problem in Pakistan. The spiral of political instabilities and external shocks actually started in 1988 and further deteriorated with the onslaught of natural calamities in 1992-93. A severe economic crisis has plagued the country since then. Deflationary Structural Adjustment (SA) Policies have compounded the difficulties. Slow economic growth, drastic cuts in the Public Sector Development Programme (PSDP), stagnant investment, downsizing in the government departments, ban on new positions and huge inflow of returning expatriates are some contributing factors in the rise of unemployment and poverty today in Pakistan. There are no jobs to accommodate the labour force growing at 3.3 percent annually. ${ }^{7}$ The government, in a desperate attempt to collect revenues, has been increasing indirect taxes that now comprise 80 percent of the total tax revenue. The speedy privatisation of the public sector corporations under the structural adjustment programme is going to result in high prices of the privatised services and subsequent rise in the utility bills is expected to push the poor further towards the wall.

The Asian Development Bank has indicated that the low economic groups are the one bearing the toll of Pakistan's economic problems and subsequent economic reform initiatives of the $1990 \mathrm{~s}{ }^{8}$ Income poverty reaching the lowest ebb of 20 percent in 1990 has risen to 30 percent once again in 1995. Economic Survey 199798 of Government of Pakistan also acknowledges that the problem of poverty has been intensified in Pakistan since early 1990. World Bank estimates show that about a third of the population of Pakistan is living below the poverty line in 1990-91. ${ }^{9}$ This proportion translated into numbers shows that almost $\mathbf{4 3 . 5}$ million people in Pakistan are living under the poverty line. Hence the problem of poverty, coupled with faltering economic growth, is turning the existing very bad situation into even worse.

\footnotetext{
${ }^{6}$ Please see Appendix B.

7"Pakistan at a Glance" http://www.worldbank.org/data/countrydata/aag/pak_aag.pdf dated 9th of March 1999

8“Country Assistance Plan Pakistan 1999-2001” Asian Development Bank 1998.

"'Recent Developments, Policy Issues and Agenda for Change" The World Bank Country Department-I South Asia Region, March 25,1997.
} 


\section{GROWTH AND DISTRIBUTION}

Economic growth has been the top policy agenda of the successive regimes in Pakistan. Some critics [like Akmal (1994)] believe that an excessive focus on "economic success" has not been a proper strategy in the past as it has been accompanied by increasing inequality, growing numbers of the poor, and a fragile and dependent economic structure. ${ }^{10}$ The evidence from the previous discussion shows that this value judgment on poverty is a bit exaggerated; nevertheless, it is not all wrong. Economic growth has contributed to reduce poverty but the intensity and extensiveness of the decline has not been on a par with economic growth. The Government of Pakistan in a recent document has acknowledged that the structure of economic growth process in Pakistan has constrained its capacity to reduce poverty. ${ }^{11}$ It states that Indonesia with a growth rate close to Pakistan's, in just one decade (1972-84) was able to reduce the percentage of its population below the poverty line from 58 percent in 1972 to only 17 percent in $1984 .^{12}$ By contrast, Pakistan in three decades (1962-1992) could reduce its poverty figure to a much lesser extent, from 40 percent in 1962 to 22 percent (a very generous estimate of Government of Pakistan) in $1992 .{ }^{13}$ The proponents of the poverty argument further contend that the natural consequence of this extreme incline towards economic growth has appeared in a neglect of the distributional aspect of growth. Development that should have been targeted at the holistic transformation of society has remained an enclave in the hands of the few and slowed the poverty alleviation process. Human Development in South Asia [UNDP (1998)] contends that strong feudal hold over the national policies and productive resources has been one of the major factors that have restrained the trickle down process. ${ }^{14}$

\section{THE HUMAN FACE OF POVERTY}

A look at the Human Poverty Index (HPI) ${ }^{15}$ developed by United Nations Development Programme (UNDP) and introduced in the Human Development Report of 1997 can help us further in investigating poverty. This index is useful as it incorporates the social aspects like health and education along with the income provisioning as a part of human poverty. Poverty of Opportunity Index (POPI) ${ }^{16}$ is

\footnotetext{
${ }^{10}$ Akmal Hussain (1994) "Poverty Alleviation in Pakistan" Vanguard Books, Lahore.

${ }^{11}$ Ninth Five Year Plan (1998-2003) "Report of the Working Group on Poverty Alleviation" Government of Pakistan, Islamabad 1998.

${ }^{12}$ Pakistan: A Strategy of Sustainable Agricultural Growth, November 1994, World Bank Report No.3902-PAK

${ }^{13}$ Ninth Five Year Plan (1998-2003) op. cit. p. 7.

14“"Human Development in South Asia” Oxford University Press. Islamabad 1998.

${ }^{15}$ It has three components i.e. deprivation in longevity, deprivation in knowledge and deprivation in economic provisioning.

${ }^{16}$ It also has three components i.e. health deprivation measure, education deprivation measure and income deprivation measure.
} 
another measure that realigns the parameters of HPI in a rather broad manner. Both the indices, however, define poverty in a multidimensional context of "denial of opportunity". It is pertinent to probe these indices to see whether they conform to the general trend of consumption poverty or depict some different picture.

The following table shows a brief historical comparison among the Income Poverty (IP), HPI and POPI in Pakistan.

Table 1

A Comparison of IP, HPI and POPI (\% of Total Population under)

\begin{tabular}{lccc}
\hline Year & Income Poverty & HPI & POPI \\
\hline 1970 & 40 & 64.8 & 61.0 \\
1975 & 35 & 61.5 & 57.7 \\
1980 & 38 & 58.6 & 56.3 \\
1985 & 25 & 54.3 & 50.9 \\
1990 & 20 & 50.3 & 46.0 \\
1995 & 30 & 47.2 & 43.7 \\
\hline
\end{tabular}

Source: Pakistan Poverty Monitor Project 1998, Human Development Centre Islamabad, Pakistan.

A perusal of the above table reveals the remarkable differences between the income poverty and the other two broader indices. The inclusion of social parameters shows that a lot more people are afflicted by HPI and POPI than by simple income or consumption poverty. ${ }^{17}$

An encouraging finding, however, is that both HPI and POPI have been consistently decreasing while the trend in income poverty has been a bit cyclical. (Please see the drastic jump in the incidence of income poverty from 1990 to 1995). ${ }^{18}$

Unfortunate enough, this is not the end of the story. The most striking finding comes into view with the comparison of male and female indices of poverty. ${ }^{19}$

${ }^{17} \mathrm{~A}$ further comparison of HPI and POPI reveals that these index levels are pathetically low at "47.2" and "43.7" when compared to "5" of developed countries (The value of HPI is "5" for the developed countries that UNDP regards as High Human Development).

${ }^{18}$ It is worth mentioning here that even the broader measures like HPI and POPI do not reflect a complete picture of poverty of opportunity. A number of social, economic and political parameters like access to land, social mobility and employment, access to the formal credit facility etc. can be included in this index.

${ }^{19}$ Only one index i.e. POPI has been used to avoid the duplication. HPI shows the similar results of initial differences and rising disparities. 

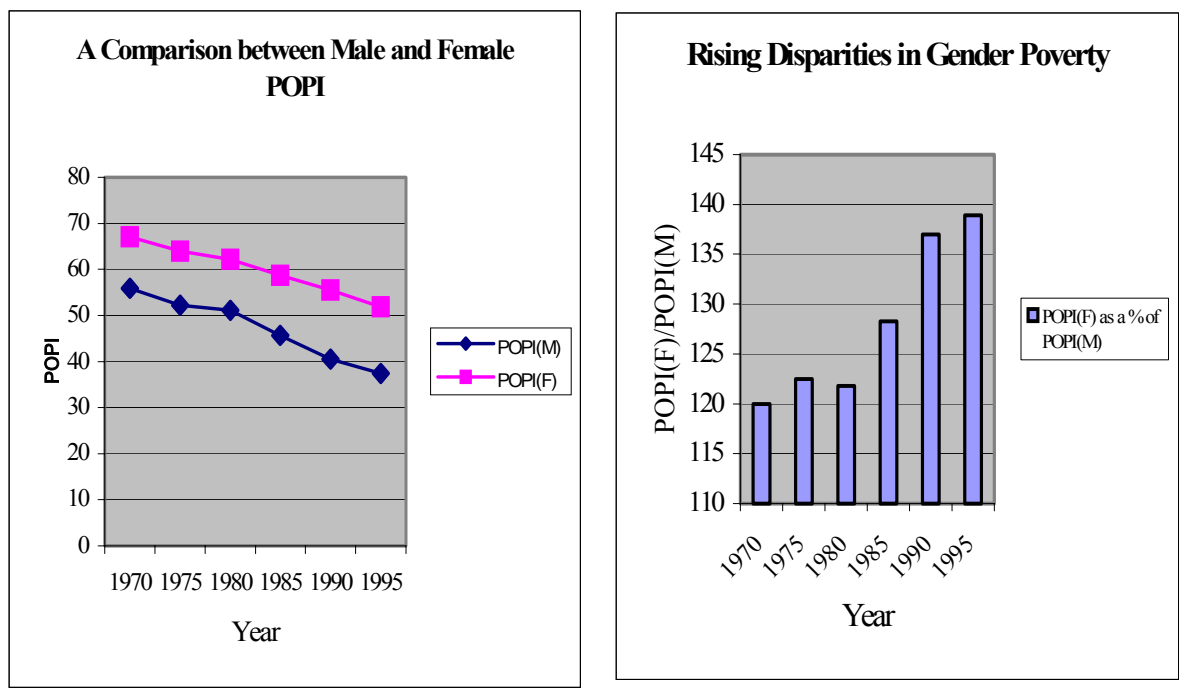

Source: Prepared from the data set of Pakistan Poverty Monitor Project 1998.

\section{Chart 1. A Reflection of Acute Incidence and Increasing Gender Poverty in Pakistan.}

The line graph of left-hand side shows an acute incidence of poverty in the female population of Pakistan. A persistent gap shows that the females have always been more deprived and poor as compared to their male counterparts. An even worse manifestation is the widening gap between the two indices. The bar chart on the right has been plotted by dividing POPI (F) by POPI (M) to show this phenomenon clearly. A successive comparative rise in female poverty and deprivation means that the women, instead of ameliorating their position relative to men, are getting worse off.

\section{Poverty and Plight of Women in Pakistan}

The World Bank in its "Country Gender Profile of Pakistan" deplores that the status of women in Pakistan is among the lowest in the world. ${ }^{20}$ UNDP (1996) details that there is a strong "inside/outside" dichotomy in Pakistan, where women are restricted to the "inside" space of home and household, embodied in the tradition of veiling. This restricts women's access to education, employment, training opportunities and available social services. ${ }^{21}$ Another World Bank (1999) report

${ }^{20}$ World Bank Report of "Country Gender Profile of Pakistan" (http://www.worldbank.org/ gender/info/pakist.htm dated 1999-02-28.

${ }^{21}$ UNDP (1996) Preparatory Assistance (PA) Document Number: PAK/96/016-“Facilitating Women's Mobility". 
laments that women and girls in poor households bear a disproportionately high burden of the share of poverty. It narrates that their greater deprivation is due to low social status, lower endowment of land and productive assets compared to men and very limited access to economic options and social services. ${ }^{22}$ Samina (1997) mentions another important aspect by stating that the social disapproval of women working outside the home translates into the invisibility of women in the labour force. Although they participate actively in the family and farm affairs, their unpaid work is perceived as a performance of social duty rather than an economic contribution. ${ }^{23}$ Stiglitz (1998) in his recent paper on gender has also lamented on the poor indicators of Pakistan in comparison to the other developing countries. ${ }^{24}$

Current social indicators of female population and its comparison with the low-income countries also depict a pathetic picture. Women's educational status in Pakistan (measured by enrollment rates) is among the lowest in the world. Only 25 percent of school age girls actually attend primary school, compared with an average of 96 percent in low-income countries. ${ }^{25}$ Dr Akmal Hussain, (Chairman of the Task Force on Poverty Alleviation in Pakistan) has rightly commented on the poverty and plight of women in Pakistan as following ${ }^{26}$

"As a result of the inferior status of women in society, their underestimation as economic agents as well as the gender bias embedded in the development policies pursued so far, most women in Pakistan have carried a double burden, that of being poor and being women".

\section{Poverty Alleviation and the Role of Formal Finance}

A number of attempts by the government to use the institutional credit have largely been confined either to the agricultural sector or medium and large-scale agro-processing ventures. The supply of such credit has increased from Pak. Rupee 1.6 billion in 1970s to Pak. Rupee 20 billion in the mid- 1990 s. $^{27}$ Despite a large increase in the number, the subsidised credit has failed to obtain the desired results. Credit Survey of 1985 testifies that three major institutional sources (the Agricultural Development Bank, Commercial Banks, and Cooperatives) have provided credit to

\footnotetext{
${ }^{22}$ World Bank (1999) Project Appraisal Document on a Proposed Credit of US\$ 90 million for a Poverty Alleviation Fund Project, Report No. 19316-Pak.

${ }^{23}$ Samina Kamal (1997) Women Empowerment and Poverty Alleviation in South Asia: The Dual Benefits of Micro Credit" p.114. South Asia Poverty Alleviation Programme UNDP.

${ }^{24}$ Stiglitz Joseph (1998) "Gender and Development: The Role of the State" Gender and Development Workshop, Washington, D. C.

${ }^{25}$ Country Gender Profile of Pakistan op. cit.

${ }^{26}$ Akmal Hussain (1994) "Poverty Alleviation in Pakistan" Vanguard Books. Lahore. Pakistan.

${ }^{27}$ Technical Assistance (TA) document of Asian Development Bank "Rural Micro Finance Project” TAR:PAK 29229, December 1997.
} 
only a small proportion of rural households. The survey reports that there were 9.24 million rural households in Pakistan, of which 5.18 million were farming households and 4.05 million, were non-farm households. Only 32 percent of the households (2.95 million) reported taking loans, and 27 percent reported outstanding debt. Of households that borrowed, a mere 10 percent $(240,000$ households) borrowed from institutional sources (ADBP, 76 percent; commercial banks, 17 percent; and cooperative societies; 6 percent). The remaining borrowed from non-institutional informal sources (friends and relatives, 67 percent; landlords, 11 percent; factories, 2 percent; and moneylenders, 2 percent).

On the other hand richer rural households had better access to cheaper institutional credit whereas poorer households depended mainly on expensive noninstitutional sources. ${ }^{28}$ These institutions, as the critics have argued generally about the rural credit programmes, failed because of the limited role of the interest rate and savings mobilisation. ${ }^{29}$ ADBP's loan recovery rate deteriorated from 55 percent in the year 1990 to below 50 percent in 1993 while the subsidy dependence is on the rise since 1991.

ADBP Subsidy Dependency Index ${ }^{30}(\%)$

\begin{tabular}{llllll}
\hline & 1988 & 1989 & 1990 & 1991 & 1992 \\
\hline SDI & 31.4 & 29.6 & 25.5 & 31.6 & 36.2 \\
Interest Rate & 11.8 & 11.9 & 11.9 & 12.5 & 12.2 \\
\hline
\end{tabular}

Source: Rural Finance for Growth and Poverty Alleviation in Pakistan, World Bank.

Hence these institutions have failed at both the fronts of targeting and outreach. A major hurdle in achieving these objectives has been the inability of the poor to serve collateral. Another important reason for the failure of these institutions has been asymmetric information (adverse selection and moral hazard) and imperfect enforcement problems. These two problems, according to Hoff and Stiglitz, ${ }^{31}$ are endemic in developing countries.

The international experience with government schemes to provide cheap credit to the rural poor has not been very encouraging. ${ }^{32}$ Only 5 percent of poor farmers in Africa and 15 percent in Asia and Latin America have had access to such

\footnotetext{
${ }^{28}$ Saeed Qureshi, Ijaz Nabi and Rashid Faruqee (1996) "Rural Finance for Growth and Poverty Alleviation in Pakistan”. World Bank Working Paper No. 1593.

${ }^{29}$ Adams, dale W., Douglas Graham, and J. D. Von Pischke (1984) "Undermining Rural Development with Cheap Credit". Boulder, Co. West View.

${ }^{30} \mathrm{SDI}$ is an index of self sustainability devised by the World Bank for the Rural Finance Institutions (RFIs). It is obtained by dividing the Annual Subsidy by the Average Annual Outstanding Loan multiplied by Average on lending Interest rate of RFI.

${ }^{31}$ Hoff, Karla and Joseph E. Stiglitz (1990) "Introduction: Imperfect Information and Rural Credit market-Puzzles and Policy Perspectives". The World Bank Economic Review 4(3):235-51.

${ }^{32}$ Reviewed in the World Development Report 1990.
} 
credit. Surveys carried out in Pakistan also conform to the general trend and show that the poorest farmers have obtained less than 6 percent of their credit from formal sources. ${ }^{33}$

Source of Loans by Asset Quintiles

\begin{tabular}{lccc}
\hline Asset Quintile & Formal Source (\%) & Family and Friends & Informal Source (\%) \\
\hline Lowest & 1.05 & 31.43 & 67.51 \\
Second & 4.83 & 49.53 & 45.63 \\
Third & 12.60 & 48.33 & 39.07 \\
Fourth & 29.62 & 35.44 & 34.95 \\
Highest & 58.36 & 20.10 & 21.54 \\
\hline
\end{tabular}

Source: IFPRI, Pakistan Panel Survey, Round 13 1990, cited in Saeed Qureshi, Ijaz Nabi and Rashid Faruqee (1996).

It is evident from the above table that the lowest and second lowest asset holders have hardly been able to benefit from the formal sources. These households, instead, have relied heavily on the informal sources. These loans from the informal sources have not been generally for some income generating activities. According to 1990 IFPRI $^{34}$ Survey, informal loans have been predominantly for consumption and it is not clear whether these loans help recipients escape poverty or not.

\section{Poverty Alleviation and the Role of Informal Finance}

The credit needs of the majority of rural poor are met in large part by informal credit sources, based essentially on personal contact and local sanction. The informal market in Pakistan can be divided into four categories i.e. socially based arrangements, commercial arrangements, a land-based system, and moneylenders.

One-third of non-institutional credit comes from friends and relatives who do not charge interest and operate on the basis of reciprocity. Friends and relatives sometimes operate through a committee system. These committees are common in developing countries and termed as ROSCAs (Rotating Savings and Loan Associations). ${ }^{35}$ Commercially based credit is linked with the supply of inputs or the purchase of output, and is common among the rural poor. The marketing intermediaries who extend the credit may be commission agents or village traders or shopkeepers. Credit from suppliers is quite popular even though the difference in prices for cash terms and credit terms may be substantial, implying a high rate of interest (ranging from 2 percent to 15 percent per month).

Land-based credit is the informal instrument used by tenants and subsistence farmers. According to the 1973 rural credit survey interest rates for this type of

\footnotetext{
${ }^{33}$ Saeed Qureshi, Ijaz Nabi and Rashid Faruqee (1996) Rural Finance for Growth and Poverty Alleviation in Pakistan. World Bank Working Paper No. 1593.

${ }^{34}$ International Food Policy Research Institute.

${ }^{35}$ Pischke, J. D.Von (1996) "Finance at the Frontier; Debt Capacity and the Role of Credit in the Private Economy" World Bank.
} 
credit were about 60 percent higher than institutional rates. ${ }^{36}$ Since independence, professional moneylenders have not been a significant part of the credit system in the rural areas. Money lending is considered an unworthy profession in Islam and its does not constitute an important source of informal credit.

Informal credit has its own limitations as well. The main limitations pertain to scale, space, and time. The market is segmented from the national financial system, reducing its capacity for financial intermediation. Informal finance is essentially a local phenomenon depending on local contacts. Its fragmented and local character is both its strength and weakness. It caters to temporary gaps in consumption, immediate unforeseen contingencies, and emergent situations. It does not promise the desired outreach and sustainable solution of credit provision to the poor and needy.

\section{Gender Focused Banking}

It is hard to assess the outreach of different government schemes to the female population of the country as no such statistics are recorded and hence no data are available. But it can be safely said that very few women could have benefited from formal schemes, as employment has been mostly a male phenomenon in Pakistan.

The Government of Pakistan, acknowledging the importance of financial services and its limited outreach to the women of Pakistan, established the First Women's Bank Limited (FWBL) in 1989. The bank is managed and run by women and aimed to work as a unique mix of a commercial bank, development finance institution, and social welfare organisation. The bank is chartered to provide traditional (deposit taking, commercial lending) and non-traditional (provision of concessional credit, advice and consultancy services to women entrepreneurs, business training and managerial skills) banking services to women. The bank has, however, failed in its objective of reaching the poor women and providing credit to female entrepreneurs. Fauzia (1997) has recorded that the bank has been able to disburse only 16 percent of its resources in the year $1995 .{ }^{37}$ Samina (1997) exploring a bit further has noticed that only 5 percent of the total disbursed advances have actually gone to the micro enterprises. ${ }^{38}$

\section{A Case for Intervention}

As mentioned earlier Pakistan enjoyed the fastest rate of GDP growth in South Asia during the 1960-90 period, this did not register adequately in equally fast reduction of poverty. Obviously economic growth failed to trickle down to the

\footnotetext{
${ }^{36}$ Rural Credit Survey 1973, Government of Pakistan, Islamabad.

${ }^{37}$ Fauzia Saeed (1997) "Preparatory Assistance Document of Women in Urban Credit" Project No. PAK/96/015/A/01/99 UNDP. Islamabad.

${ }^{38}$ Samina Kamal (1997) "Women Empowerment and Poverty Alleviation in South Asia: The Dual Benefits of Microcredit" South Asia Poverty Alleviation Programme of UNDP.
} 
masses because of the feudal hold over the distribution of income. ${ }^{39}$ The role of the government in transferring income and opportunities to the poor has also remained marginal. The government in the past, for example, has transferred only 0.2 percent of the GNP (per annum) to the poor through Zakat and Bait-ul-Mal. ${ }^{40}$

\section{Justification of a Special Institution}

The pivot of banking business is "collateral" which serves as an explicit guarantee against the possible risk associated with the inter-temporal trade of money. One who does not have this explicit or implicit guarantee is not considered bankable. The poor in the past have not been able to tap formal credit from the existing institutions on these grounds. This denial of opportunity has bound them in a vicious circle. They remain poor because they are already in a poverty trap of low initial endowments, low income, low savings and low investment. The poverty of opportunity, on the other hand, has worsened their ability to tap their capabilities in the direction of "self actualisation". ${ }^{41}$ These poor need credit as the markets have failed to provide credit to them. They have not been able to satisfy the collateral requirements grounded in individual property rights. The annual report 1996 of Kashaf Foundation (an NGO active in the Micro banking business in Pakistan) also emphasises the necessity of banking with the poor and especially women in the following words

"One very genuine reason to bank is that the financial markets are prone to neglect the needs of the rural poor women, simply because the existing criteria of financial worthiness requires contacts, collateral and accessibility".

Furthermore, lending to the poor is also an important equity objective both because reduction in income inequality per se is often a social goal and because poverty reduction contributes to political stability and thus facilitates growth. ${ }^{43}$

An institution need to be created that overcomes market failure due to the high risk and high transaction costs associated with lending to small borrowers. That institution should provide banking services for the rural poor. Provision of institutional credit will work not only for consumption smoothing but also to promote sustainable income generation activities. In the absence of access to formal source of credit, the poor are expected to remain at the mercy of exploitative and non-reliable sources of finance.

\footnotetext{
${ }^{39}$ Human Development in South Asia (1998) Oxford University Press.

${ }^{40}$ Zakat and bait-ul-mal are the Islamic social safety nets.

${ }^{41}$ Akmal Hussein: Poverty Alleviation in Pakistan (1994) Vanguard Books (Pvt.) Limited Lahore.

${ }^{42}$ Kashf Foundation Annual Report 1996, Lahore, Pakistan.

${ }^{43}$ Saeed Qureshi, Ijaz Nabi and Rashid Faruqee (1996) Rural Finance for Growth and Poverty Alleviation in Pakistan. World Bank Working Paper No. 1593.
} 


\section{Micro Finance; the Prescription}

As mentioned earlier, government efforts of targeting the poor through subsidised credit have not been successful in the past. Firstly, the cheap credit has leaked to the relatively richer rural households. Secondly, the subsidy dependence of these institutions required regular injection of government and donor funds and these institutions could not become sustainable. Thirdly and most importantly, only a fraction of the credit could flow to the women poor who are the most deprived of the poor. Hence these institutions have not been successful both in terms of outreach and sustainability.

The informal finance, as outlined earlier, has been expensive, exploitative and chancy with a fragmented market. This has necessitated some institutional mechanism that could reach the poorest of the poor in a sustainable manner. Some NGOs in Pakistan like Agha Khan Rural Support Programme (AKRSP) and National Rural Support Programme (NRSP) have tried in the past to cover these deficiencies by extending a package of social services and credit to the poor and met with limited success. But the problem with this approach is what has been mentioned (by Saeed Qureshi, Ijaz Nabi and Rashid Faruqee, 1996) that the mandate of these programmes is too broad. Even the highly acclaimed Comilla Cooperative Model (in the East Pakistan now Bangladesh), which attained considerable success in the early years suffered serious repayment and viability problems when the government replicated it nationwide. $^{44}$

\section{Plausibility of Grameen Type Banking in Pakistan}

Grameen Bank of Bangladesh has emerged as a successful NGO credit programme for rural poverty alleviation. Grameen in Bengali language is a verbatim for "rural". Grameen Bank is a private rural bank in Bangladesh that provides financial services (especially credit) to the poor and particularly women. ${ }^{45}$ It was

\footnotetext{
${ }^{44}$ Ismael Getubig, Jr. (1993) The Role of Credit in Poverty Alleviation: The Asian Experience. In the Design and Management of Sustainable Projects to Alleviate Poverty in South Asia. Economic Development Institute of the World Bank.

${ }^{45}$ Professor Yunus has justified his stance of priority for women in many papers. In his paper titled "Grameen Bank-The First Decade: 1976-86" for example, he describes the plight of women in these words "To see the real face of our society, we have to look at it with the eyes of our women. Then there will be no way to hide its ugly scars. This is especially true if the experience is that of the impoverished women. All the devices of social oppression, in fact, are indiscriminately practiced on women who are poor...A large number of impoverished women are those who have been abandoned, divorced or persecuted by their husbands. Our society is reluctant even to admit the notion that such women may have separate identities and independent potential...People who experience the most cruel manifestations of poverty are the women from the poor households. When there is scarcity even the husband disappears. A father can run away in order not to confront his starving children, but the mother can not... No one has to cope with poverty the way a poor woman does throughout her lifetime. Poverty does not humiliate and crush a man the way it does a woman." In another paper "Grameen Bank: Some Thoughts and Experience" he argues that under the toughest survival conditions, women, when given a little opportunity, struggle extra hard to get out of it.
} 
started in 1976 by Mohammad Yunus, an economics professor of Chittongong University of Bangladesh. He provided tiny collateral-free production loans to the poor to judge their capacity to use that money and observe their repayment behaviour. The repeated experiments showed that the poor borrowers could invest money to generate small streams of income that helped them smooth their consumption. They also proved trustworthy in returning the borrowed money without any exception. This led Prof. Yunus to dispel the conventional idea that the poor were not bankable due to their precarious financial position and lack of collateral. The initial success and repeated trustworthy behaviour of the poor let him think to institutionalise the mechanism, which resulted in the establishment of the Grameen Bank. The Central Bank of Bangladesh acknowledged Grameen as a financial intermediary in 1983 and permitted it to operate as a specialised financial institution with a specific mandate to serve the poor.

The Grameen philosophy of financial intermediation is based on the notion that lack of access to credit is the biggest constraint for the poor. ${ }^{46}$ The Bank believes that with appropriate credit support, the poor can be productively employed in income generating activities as they already have some survival knowledge of subsistence activities. Unlike traditional commercial banks, Grameen loans are collateral free. Grameen Bank also maintains that if the rural poor are provided credit on reasonable terms, they can judge for themselves their activities and inputs to start a tiny business. Based on these notions, Grameen Bank creates the social and financial conditions enabling poor men and (especially) women to receive credit who identify for themselves a source of self-employment and by agreeing to guarantee and monitor others in their self-selected group. In addition to financial intermediation, it conducts social intermediation to make the poor both socially and individually accountable. Such accountability leads to more effective use of loans and consequently ensures loan recovery. ${ }^{47}$

As of February 1999, Grameen Bank had 1,138 branches serving approximately 2.37 million borrowers including 2.24 million female borrowers (more than 94 percent) at their doorsteps in 39,172 villages (around 58 percent of the 68,000 villages of Bangladesh). ${ }^{48}$ Fifty million or a half of the total 100 million rural population in Bangladesh is living in abject poverty (and hence qualify to be a Grameen member) with an average household size of somewhat greater than five. ${ }^{49}$ This means that Grameen has reached almost a fifth of the rural population that lives in poverty.

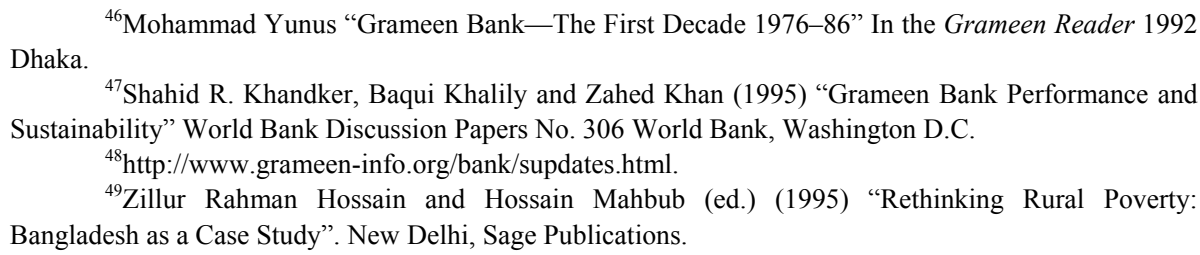


Infusion of concessionary funds and grants played a good role in the development of Grameen Bank especially in the early phase. But the evidence shows that the bank fast reduced its dependence on these inputs and subsidies. The figures released by Khandker et al. (1995) indicate a sharp decline in the subsidy dependence of Grameen Bank. They found that subsidy declined rapidly from 21 percent in 1991 to 3.72 percent in 1994 on per taka loans outstanding. Their final word on the sustainability analysis goes as follows "given its operational cost and sources of funding, the Grameen Bank is financially viable".

\section{Impact Assessment}

A village level wage impact analysis (by taking the rural wages as an indicator of rural poverty and looking at the effect of bank operations on village level wages) suggests that the Grameen Bank had a significant positive effect on the wages. The results of the analysis were robust given that the Grameen Bank placed its program in villages where 65 percent of households were eligible compared with 52 percent of the households in the non-programme villages. ${ }^{50}$ Another study based on a structured survey of 975 borrowers in 15 villages has produced several types of evidence (in terms of employment, income and increases in per capita food consumption) indicating a positive impact on the economic status of the Grameen borrowers. ${ }^{51}$ Khandker and Chowdhury (1995) in a joint study with the Bangladesh Institute of Development Studies (BIDS) have shown that Grameen Bank (along with two other microcredit programmes) has not only reduced poverty and improved welfare of participating households, but also enhanced the households' capacity to sustain their gains over income. ${ }^{52}$

A couple of studies [Schuler and Hashemi (1994), Hashemi et al. (1996), Schuler et al. (1997)] reflect a positive social impact in terms of reproductive behaviours on the female members of Grameen. Both Hashemi et al. (1996) ${ }^{53}$ and Schuler $(1997)^{54}$ find significant effects of membership of Grameen Bank on both

${ }^{50} \mathrm{Ibid}$. p. 78.

${ }^{51}$ Hossain Mahbub (1988) "Credit for Alleviation of Rural Poverty: The Grameen Bank in Bangladesh" International Food Policy Research Institute, Research Report No. 55 Washington, D.C. pp. $58-69$.

${ }^{52}$ Khandker Shahidur R. and Chowdhury Osman H. (1995) "Targeted Credit Programmes and Rural Poverty in Bangladesh" prepared for the workshop "Credit Programmes and the Poor" March 19-22 1995 Dhaka Bangladesh Education and Social Policy Department, The World Bank and Bangladesh Institute of Development Studies.

${ }^{53}$ Hashemi Syed M., Sidney Ruth Schuler and Ann P. Riley (1996) "Rural Credit Programme and Women's Empowerment in Bangladesh". World Development 24:4

${ }^{54}$ Schuler, Sidney Ruth, Syed M. Hashemi, and Ann P Riley (1997) “The Influence of Women's Changing Roles and Status in Bangladesh's Fertility Transition: Evidence from a Study of Credit Programmes and Contraceptive Use". World Development 25:4. 
women's empowerment ${ }^{55}$ and contraceptive use. They also contend that these effects increase with the increased duration of women's exposure to the bank.

\section{Grameen Performance and Update}

The official figures ${ }^{56}$ released by the Grameen Bank in June 1998 show that it had a work force of nearly 13000 operating in 66,202 centres and 1,115 branches. On any working day, Grameen collects an average of $\$ 1.5$ million in weekly instalments. A total of 443,636 houses have been built with the Grameen housing loans. Total group fund savings on 30th June 1998 stood at US\$ 182.76 million while the number for the individual savings was 17.25 million dollars. Khandker $(1995)^{57}$ has lauded the exceptional performance of the Grameen Bank in mobilising savings. He enumerates that the savings have grown at an average growth rate of 41 percent from 1985-94. A comparison of Grameen with the contemporary commercial banks shows that the total savings mobilised by Grameen in 1984 have been four times that of the combined savings generated by the five commercial banks together.

The loan collection record of the Grameen has also been commendable. No Grameen bank borrowers were defaulters between 1985-1986 while only 1 percent were defaulters during 1987-89. This figure rose to 3 percent by 1992, but fell back to 1 percent in 1993 and declined further in 1994. Khandker et al. $(1995)^{58}$ contend that irrespective of the way loan defaulters are defined (although the men on average default more than women) the data reveal that the overall proportion of borrowers who default is very small.

Grameen Bank's total of loans disbursed has topped US\$ 2.44 billion. Grameen crossed the first billion dollars mark in March 1995, about eighteen years after starting its journey in 1976. It took only twenty-seven months to lend the second billion dollars. The total amount of loans that Grameen Bank disburses each year exceeds the total amount of rural loans disbursed by all other banks in Bangladesh put together. Grameen has stopped negotiating for new grants or soft loans since 1995 deciding to depend fully on commercial sources of funding. ${ }^{59}$ The most thrilling experience for Grameen came in 1994-1995 when it issued bonds to raise $\$ 160.75$ million from the commercial banks in Bangladesh. That has helped Grameen to pay back the central bank loan and create loanable fund on a long-term basis.

\footnotetext{
${ }^{55}$ Women empowerment being a qualitative phenomenon is difficult to judge. The authors use eight different indicators like freedom of movement, economic security, ability to make small and large purchases, participation in important family decisions etc. that encompass the various aspects of women's role and status.

${ }^{56}$ These facts and figures are quoted from the Grameen homepage at http://www.grameeninfo.org/bank/lookbs.html.

${ }^{57}$ Khandker (1995) op cit., p. 29-30.

${ }^{58} \mathrm{Ibid}$. p. 76.

${ }^{59}$ It, however, continued to receive grant and soft loans during 1996-97 under agreements negotiated before 1996. These came to an end in June 1998.
} 
Grameen with a total paid up capital of 5.23 million dollars is owned by its members (92.68 percent shares of the bank are held by the members while the rest 7.32 percent by the government). ${ }^{60}$

\section{Cloning the Model}

Successful financial and social intermediation of the Grameen model in Bangladesh suggests thinking of its replication in Pakistan where poverty has similar rural and gender dimensions. Gibbons ${ }^{61}$ delineates two conditions for the successful replication of the Grameen Bank; a market economy and no strong opposition from political authorities. These two conditions appear to be a rather oversimplified representation of the process as, replication, generally speaking, should not be a merely static transplantation of the model from one place to another. But a closer look at the model, its working and operations reveal its sheer simplicity. Its successful history of working with the extremely poor in many countries confirms its context neutral nature and substantiates this argument. The model although novel in its approach and operations is nothing but a specialised banking service. (Here I would like to mention that even a market economy is not a necessary condition as Vietnam has very successfully replicated this model and the replication named "TYM" is doing fairly well).

The simplicity of the Grameen model and its stunning success in the pursuit of achieving its objectives have convinced many countries to replicate this model (either through private initiatives or government programmes) in the recent past. As many as 168 such programs have been implemented recently in 44 countries. $^{62}$ Project Amanah Ikhtiar Malaysia (AIM) is a vivid example of successful replication of the Grameen Bank. ${ }^{63}$

\section{CONCLUSION}

Poverty in Pakistan, despite many checkered attempts, has persisted widely. In the current decade its levels are rising and certain other domestic factors are worsening the misery of the poor and especially women. The government has failed to provide institutional credit to the poor in the past. Changing socio-economic conditions and transition of society to a formal phase are reducing the chances of

\footnotetext{
${ }^{60}$ The discussion on the Grameen Bank, heavily relies on certain sources and studies that describe the working, organisational structure and operations etc. of the bank e.g. Khandker et al. (1995), Hashemi et al. (1997), Home page of Grameen Bank etc.

${ }^{61}$ Gibbons David S. (1992) “The Grameen Reader” Dhaka Bangladesh.

${ }^{62}$ Khandker et al. (1995) op cit., p. 87.

${ }^{63} \mathrm{Ibid}$.

Draft Report of the World Bank on "Social Impact of the East Asian Crisis" has also quoted Mcquire and Conroy (1998): 7-9 at. http://www.worldbank.org/poverty/eacrisis/library/soccimp1p3.htm. It says that there is anecdotal evidence that AIM has been important for women in Malaysia. ... In short, Microfinance has been instrumental in protecting vulnerable groups.
} 
informal credit. Social safety nets are almost non-existent. Development in general, remains devoid of what Stiglitz ${ }^{64}$ calls "Social transformation". Structural imbalances in the growth process (continuation of pure growth strategies, strong feudal hold over means of production and lack of land reforms etc.) continue to exist. Under these circumstances, any further (public or private) efforts in the direction of development need to be holistic that especially address the lower strata of society.

The persistence of poverty in Pakistan is rooted in socio political inequalities. In such societies, according to Yarn (1992) individual based lending can "perpetuate and reinforce the existing socio-economic inequities and access to scarce financial resources". ${ }^{65}$ Under these circumstances there is a dire need of learning from the proven group based lending of Grameen Bank. The beauty of Grameen approach lies in its peculiar mechanism that ensures reaching these lowest strata of society in a sustainable fashion. Secondly it does not dole out money to counter the problem of poverty. As Grameen is heading fast to reach the maximum poor and help them empower against multifaceted poverty, so is desired today in Pakistan through an effective institutional mechanism.

${ }^{64}$ Stiglitz, Joseph E. (1998a) “Towards a New Paradigm of Development: Strategies, Policies and Processes". Lecture at UNCTAD, Geneva Oct 19, 1998.

${ }^{65}$ Yaron, Jacob (1992) "Successful Rural Finance Institutions". World Bank Discussion Paper 150. Washington, D.C. 
Appendices

Appendix A

Economic Growth and Reduction in Consumption Poverty

\begin{tabular}{lcccc}
\hline & \multicolumn{4}{c}{ (GDP Figures are in Constant 1980-81 Market Prices) } \\
\cline { 2 - 5 } Year & GDP(Rs Billion) & GDP Per Capita (Rs) & $\begin{array}{c}\text { Private Consumption } \\
\text { (Rs Billion) }\end{array}$ & $\begin{array}{c}\text { Per Capita Private } \\
\text { Consumption }\end{array}$ \\
\hline $1972-73$ & & & 139.6 & 2118 \\
$1973-74$ & 176.9 & 2684 & 161.4 & 2377 \\
$1974-75$ & 183.1 & 2697 & 158 & 2258 \\
$1975-76$ & 190.9 & 2728 & 165.6 & 2296 \\
$1976-77$ & 200.7 & 2783 & 177.8 & 2392 \\
$1977-78$ & 208.6 & 2807 & 192.4 & 2512 \\
$1978-79$ & 225.4 & 2943 & 213.4 & 2703 \\
$1979-80$ & 233.9 & 2963 & 230.2 & 2830 \\
$1980-81$ & 257.8 & 3169 & 224.1 & 2673 \\
$1981-82$ & 278.2 & 3318 & 234.2 & 2709 \\
$1982-83$ & 296.4 & 3429 & 243.7 & 2735 \\
$1983-84$ & 316.5 & 3551 & 258.7 & 2816 \\
$1984-85$ & 332.5 & 3619 & 281.2 & 2968 \\
$1985-86$ & 357.7 & 3776 & 278.2 & 2848 \\
$1986-87$ & 377.5 & 3865 & 288 & 2860 \\
$1987-88$ & 401.8 & 3990 & 317.3 & 3056 \\
$1988-89$ & 433 & 4171 & 319.9 & 2988 \\
$1989-90$ & 453.9 & 4240 & 334.3 & 3029 \\
$1990-91$ & 474.1 & 4296 & 329.9 & 2899 \\
\hline Sorce: Pakista & 500 & 4394 & & \\
\hline
\end{tabular}

Source: Pakistan Poverty Assessment, World Bank 1995. 
Appendix B

An Overview of Studies on Poverty

\begin{tabular}{|c|c|c|c|c|c|c|c|c|}
\hline \multirow[b]{2}{*}{ Author } & \multicolumn{8}{|c|}{ Poverty } \\
\hline & Poverty Criteria & Region & Line & 1963-64 & $1969-70$ & 1971-72 & 1978-79 & 1984-85 \\
\hline \multirow[t]{4}{*}{ Naseem (1973) } & \multirow{4}{*}{$\begin{array}{l}\text { Annual Expenditure/Capita in 1959-60 Rs } \\
\text { (\% Population Below) }\end{array}$} & Rural & 250 & 43 & 26 & 19 & & \\
\hline & & & 300 & 60 & 60 & 58 & & \\
\hline & & Urban & 300 & 55 & 25 & 25 & & \\
\hline & & & 375 & 70 & 59 & 63 & & \\
\hline \multirow[t]{4}{*}{ Allauddin (1975) } & \multirow{4}{*}{$\begin{array}{l}\text { Annual Income/Capita in 1959-60 Rs } \\
\text { (\% Population Below) }\end{array}$} & Rural & 250 & 56 & 36 & 42 & & \\
\hline & & & 300 & 67 & 61 & 65 & & \\
\hline & & Urban & 300 & 50 & 30 & 27 & & \\
\hline & & & 375 & 71 & 60 & 62 & & \\
\hline \multirow[t]{4}{*}{ Naseem (1977) } & \multirow{4}{*}{$\begin{array}{l}\text { RDA* of } 2100 \text { Calories in } 1959-60 \text { Rs } \\
\text { (\% Population Below) }\end{array}$} & Rural & & 72 & 68 & 74 & & \\
\hline & & & $95 \%$ RDA & 54 & 46 & 55 & & \\
\hline & & & $92 \%$ RDA & 45 & 36 & 43 & & \\
\hline & & & $90 \%$ RDA & & & & & \\
\hline \multirow[t]{4}{*}{ Mujahid (1978) } & \multirow{4}{*}{$\begin{array}{l}\text { Annual Expenditure/Capita in 1959-60 Rs } \\
\text { (\% Population Below) }\end{array}$} & Rural & 250 & 29 & 39 & & & \\
\hline & & & 300 & 42 & 53 & & & \\
\hline & & Urban & 300 & 39 & 34 & & & \\
\hline & & & 375 & 55 & 52 & & & \\
\hline \multirow{2}{*}{$\begin{array}{l}\text { Irfan and Amjad } \\
\text { (1984) }\end{array}$} & Monthly Income/Capita Giving Intake of 2550 & Rural & 109 & 41 & 55 & & 41 & \\
\hline & $\begin{array}{l}\text { Calories in } 1979 \text { Rs } \\
\text { (\% Population) }\end{array}$ & & 95 & 32 & 43 & & 29 & \\
\hline Krujik and & Monthly HH Income in 1979 Rs & Rural & 700 & & 73 & & 51 & \\
\hline Leeuwan (1985) & $(\% \mathrm{HHs})$ & Urban & 700 & & 50 & & 30 & \\
\hline
\end{tabular}




\begin{tabular}{|c|c|c|c|c|c|c|c|c|c|c|}
\hline \multicolumn{11}{|c|}{ Append1x B-(Continued) } \\
\hline Author & Poverty Criteria & Region & Line & $1969-70$ & $1978-79$ & $1984-85$ & 1986-87 & $1987-88$ & 1990-91 & 1993-94 \\
\hline \multirow{4}{*}{ Malik (1988) } & Monthly Consumption/Capita in & Rural & 159 & 39 & 49 & & 33 & 26 & & \\
\hline & 1984-85 Rs & & 172 & 45 & 55 & & 39 & 31 & & \\
\hline & (\% Population) & Urban & 185 & 45 & 39 & & 26 & 21 & & \\
\hline & & & 207 & 52 & 48 & & 31 & 26 & & \\
\hline \multirow{2}{*}{$\begin{array}{l}\text { Ahmed and Allison } \\
\text { (1990) }\end{array}$} & Monthly Expenditure/Capita in & Rural & 100 & & & & 30 & 24 & & \\
\hline & $\begin{array}{l}1979 \text { Rs } \\
\text { (\% Population) }\end{array}$ & Urban & 110 & & & & 23 & 20 & & \\
\hline \multirow[t]{3}{*}{ Ercelawn (1989) } & Annual Expenditure/Capita for & & & & & & & & & \\
\hline & 2250 Calories RDA & Rural & 1524 & 46 & 36 & 28 & & 16 & & \\
\hline & (\% HHs) & Urban & 1584 & 51 & 43 & 30 & & 21 & & \\
\hline \multirow[t]{2}{*}{ Malik (1995) } & 2550 Calories RDA & Rural & & & & & & 20 & 21 & \\
\hline & $(\% \mathrm{HHs})$ & Urban & & & & & & 9 & 10 & \\
\hline \multirow{3}{*}{$\begin{array}{l}\text { Gazdar, Howes and } \\
\text { Zaidi (1993) }\end{array}$} & Monthly Expenditure/Capita on & Pakistan & 288 & & & 44 & & 35 & 34 & \\
\hline & Basic Needs in 1984-85 Rs & Rural & 288 & & & 46 & & 37 & 34 & \\
\hline & (\% Population) & Urban & 351 & & & 39 & & 30 & 31 & \\
\hline \multirow{9}{*}{$\begin{array}{l}\text { Jafri and Khattak } \\
\text { (1995) }\end{array}$} & Monthly Expenditure/Capita on & Pakistan & 224 & & & & 27 & & 23 & 21 \\
\hline & B2250 Calories RDA in Current Rs & Rural & 224 & & & & 29 & & 26 & 24 \\
\hline & (\% Population) & Urban & 224 & & & & 24 & & 18 & 15 \\
\hline & Monthly Expenditure/Capita on & Pakistan & 384 & & & & 29 & & 26 & 29 \\
\hline & Basic Needs & Rural & 343 & & & & 28 & & 25 & 25 \\
\hline & (\% Population) & Urban & 450 & & & & 30 & & 27 & 27 \\
\hline & Monthly Income/Capita on Basic & Pakistan & & & & & 29 & & 29 & 36 \\
\hline & Needs & Rural & & & & & 28 & & 29 & 37 \\
\hline & (\% Population) & Urban & & & & & 29 & & 31 & 30 \\
\hline
\end{tabular}

"RDA Stands for Required Dietary Allowance. 


\section{REFERENCES}

Adams, dale W., Douglas Graham, and J. D. Von Pischke (1984) Undermining Rural Development with Cheap Credit. Boulder, Co. West view.

Asian Development Bank (1987) Technical Assistance (TA) Document of Asian Development Bank "Rural Micro Finance Project" TAR:PAK 29229.

Asian Development Bank (1998) Country Assistance Plan Pakistan 1999-2001.

Fauzia, Saeed (1997) Preparatory Assistance Document of Women in Urban Credit. UNDP, Islamabad. (Project No. PAK/96/015/A/01/99.)

Gibbons, David S. (1992) The Grameen Reader. Dhaka: Bangladesh.

Hashemi, Syed M., Sidney Ruth Schuler, and Ann P. Riley (1996) Rural Credit Programme and Women's Empowerment in Bangladesh. World Development 24:4.

Hoff, Karla, and Joseph E. Stiglitz (1990) Introduction: Imperfect Information and Rural Credit Market-Puzzles and Policy Perspectives. The World Bank Economic Review 4:3 235-51.

Hossain, Mahbub (1988) Credit for Alleviation of Rural Poverty: The Grameen Bank in Bangladesh. International Food Policy Research Institute (Research Report No. $55)$.

Hussain, Akmal (1994) Poverty Alleviation in Pakistan. Lahore: Vanguard Books.

Ismael, Getubig, Jr. (1993) The Role of Credit in Poverty Alleviation: The Asian Experience. In the Design and Management of Sustainable Projects to Alleviate Poverty in South Asia. Economic Development Institute of the World Bank.

Jafri, S. M. Younus (1999) Assessing Poverty in Pakistan. In A Profile of Poverty in Pakistan. Mahbub ul Haq Centre for Human Development, Islamabad.

Kashf Foundation (1996) Annual Report. Lahore: Pakistan.

Khandker, Shahid R., and Chowdhury Osman H. (1995) Targeted Credit Programmes and Rural Poverty in Bangladesh. Prepared for the Workshop "Credit Programmes and the Poor" March 19-22. Dhaka: Bangladesh Education and Social Policy Department, The World Bank and Bangladesh Institute of Development Studies.

Khandker, Shahid R., Baqui Khalily, and Zahed Khan (1995) Grameen Bank Performance and Sustainability. World Bank, Washington, D. C. (World Bank Discussion Papers No. 306.)

"Pakistan at a Glance"

Pakistan, Government of (1973) Rural Credit Survey, Islamabad.

Pakistan, Government of (1998) Ninth Five-Year Plan (1998-2003). Report of the Working Group on Poverty Alleviation. Islamabad.

Pakistan, Government of (1998) Population and Housing Census of Pakistan 1998. Statistics Division.

Pischke, J. D. Von (1996) Finance at the Frontier; Debt Capacity and the Role of Credit in the Private Economy. World Bank. 
Rahman, Hossain Zillur, and Hossain Mahbub (ed.) (1995) Rethinking Rural Poverty: Bangladesh as a Case Study. New Delhi: Sage Publications.

Saeed Qureshi, Ijaz Nabi, and Rashid Faruqee (1996) Rural Finance for Growth and Poverty Alleviation in Pakistan. (World Bank Working Paper No. 1593.)

Samina, Kamal (1997) Women Empowerment and Poverty Alleviation in South Asia: The Dual Benefits of Micro Credit. p. 114. South Asia Poverty Alleviation Programme UNDP.

Schuler, Sidney Ruth, and Syed M. Hashemi (1994) Credit Programmes, Women's Empowerment and Contraceptive Use in Rural Bangladesh. Studies in Family Planning 25:2 65-76.

Schuler, Sidney Ruth, Syed M. Hashemi, and Ann P. Riley (1997) The Influence of Women's Changing Roles and Status in Bangladesh's Fertility Transition: Evidence from a Study of Credit Programmes and Contraceptive Use. World Development 25:4.

Stiglitz, Joseph (1998) Gender and Development: The Role of the State. Gender and Development Workshop, Washington, D. C.

Stiglitz, Joseph E. (1998) Towards a New Paradigm of Development: Strategies, Policies and Processes. Lecture at UNCTAD, Geneva Oct 19.

UNDP (1996) Preparatory Assistance (PA) Document Number: PAK/96/016 Facilitating Women's Mobility. Pakistan.

UNDP (1998) Human Development in South Asia 1998. Islamabad: Oxford University Press.

World Bank (1994) Pakistan: A Strategy of Sustainable Agricultural Growth, November. (World Bank Report No.3902-PAK.)

World Bank (1995) Pakistan Poverty Assessment. World Bank, Washington D.C.

World Bank (1997) Recent Developments, Policy Issues and Agenda for Change The World Bank Country Department-I South Asia Region, March 25.

World Bank (1997) World Development Report (1997). Washington, D. C.: World Bank.

World Bank (1999) Project Appraisal Document on a Proposed Credit of US\$ 90 Million for a Poverty Alleviation Fund Project. (Report No. 19316-Pak.)

Yaron, Jacob (1992) Successful Rural Finance Institutions. Washington, D. C. (World Bank Discussion Paper 150.)

Yunus, Mohammad (1992) Grameen Bank-The First Decade 1976-86. In the Grameen Reader. Dhaka.

http://www.worldbank.org/data/countrydata/aag/pak_aag.pdf dated 9th of March 1999.

World Bank Report of "Country Gender Profile of Pakistan"

(http://www.worldbank.org/gender/info/pakist.htm dated 1999-02-28

Draft Report of the World Bank on "Social Impact of the East Asian Crisis"at. http://www.worldbank.org/poverty/eacrisis/library/soccimp1p3.htm.

Grameen Homepage at http://www.grameen-info.org/bank/lookbs.html. 


\section{Comments}

This is a well-structured paper on poverty in Pakistan and the attempts to alleviate that I am impressed by the researcher's reading and recourse to different source. There is no original data as such but an inspiring analysis of the poverty problem, its prevalence, the role of formal and informal finance in alleviation and the subsequent prescription of Grameen Model. The analysis is rational and has a logical sequence leading to the necessity of an effective intermediation at the grass roots level.

Different research studies quoted in the paper reflect that the Grameen model has worked quite well in Bangladesh and can be equally successful in Pakistan. There is no doubt that poverty has been a persistent development problem of Pakistan and also has a woman face but keeping in view the different social and cultural milieu, it will be a bit of over exaggeration to talk of its absolute replication.

I have certain other reservations as follows:

1. How the Grameen replication is going to be different from the existing Micro credit programmes in the country like that of AKRSP and NRSP etc.

2. The proposal to establish an institution is open ended and it is not very clear who is supposed to take this initiative, the government, private sector or NGOs etc.

3. The third question is regarding the seed money and the modalities. Who is going to provide the seed money for such an institution and how the organisations to be engaged in this business will be educated in the complex Grameen operations.

4. Do not you think that instead of creating a new institution the existing institutions like ADBP, or Women Development Bank can be overhauled or reinvigorated to start such operation?

Pakistan Institute of Development Economics,

Zafar Mueen Nasir

Islamabad. 